Article

\title{
Synthesis and Characterization of Alkali Metal Ion-Binding Copolymers Bearing Dibenzo-24-crown-8 Ether Moieties
}

\author{
Da-Ming Wang, Yuji Aso, Hitomi Ohara and Tomonari Tanaka * \\ Department of Biobased Materials Science, Graduate School of Science and Technology, Kyoto Institute of \\ Technology, Kyoto 606-8585, Japan; d6861002@edu.kit.ac.jp (D.M.W.); aso@kit.ac.jp (Y.A.); ohara@kit.ac.jp (H.O.) \\ * Correspondence: t-tanaka@kit.ac.jp; Tel.: +81-75-724-7802
}

Received: 23 August 2018; Accepted: 28 September 2018; Published: 2 October 2018

\begin{abstract}
Dibenzo-24-crown-8 (DB24C8)-bearing copolymers were synthesized by radical copolymerization using a DB24C8-carrying acrylamide derivative and $N$-isopropylacrylamide monomers. The cloud point of the resulting copolymers changed in aqueous solution in the presence of cesium ions. In addition, the ${ }^{1} \mathrm{H}$ NMR signals of DB24C8-bearing copolymers shifted in the presence of alkali metal. This shift was more pronounced following the addition of $\mathrm{Cs}^{+}$compared to $\mathrm{Rb}^{+}, \mathrm{K}^{+}, \mathrm{Na}^{+}$, and $\mathrm{Li}^{+}$ions due to recognition of the $\mathrm{Cs}^{+}$ion by DB24C8.
\end{abstract}

Keywords: crown ether; radical polymerization; molecular recognition; alkali metal; cesium

\section{Introduction}

The general population is exposed to few cesium compounds, which are mildly toxic due to the chemical similarity of cesium and potassium [1,2]. Radiocesium is a common component of nuclear fission products. Radioactive waste treatment gained importance following the crisis at the Fukushima Daiichi Nuclear Power Plant in Japan in 2011. In particular, the radiocesium isotopes ${ }^{134} \mathrm{Cs}$ and ${ }^{137} \mathrm{Cs}$, which have half-lives of 2.1 years and 30.2 years, respectively, pose significant long-term human health concerns [3], but the development of efficient and selective reagents for adsorbing cesium from aqueous environments remains challenging [4].

Crown ethers are macrocyclic compounds with the unique property of binding specific metal ions in their cavity, depending on the size of the cavity $[5,6]$. For example, large 24-crown-8 ethers can bind specific metal ions, including cesium [7-13], and are used to extract cesium from aqueous environments [14], to form cesium ion-imprinted polymer nanoparticles [2], and to adsorb and immobilize cesium in inorganic silica material [15]. We therefore predicted that the incorporation of a 24-crown-8 ether into a synthetic polymer backbone would provide a useful material capable of the molecular recognition of specific metal ions such as cesium.

Poly ( $\mathrm{N}$-isopropylacrylamide) (PNIPAM) is well-known as a temperature-responsive polymer and has a cloud point in water of around $32{ }^{\circ} \mathrm{C}$. Hydrogen bonds form between water and the amide groups below the cloud point, making PNIPAM solutions transparent. In contrast, when the solution temperature is above the cloud point, the hydrogen bonds collapse and an aggregation forms. The incorporation of hydrophilic or hydrophobic co-monomers allows the cloud point of copolymers to be tuned. The attractive and tunable properties of PNIPAM has resulted in the synthesis of many copolymers and hydrogels using PNIPAM which are used in various applications such as drug delivery and recyclable absorbents [16-23].

Several PNIPAM linear copolymers containing benzo-18-crown-6 $[17,24,25]$, benzo-12crown-4 [25], benzo-15-crown-5 [25], and dibenzo-18-crown-6 monomers [26] have been, reported and 
exhibit both temperature-responsive and ion-recognition properties (i.e., their cloud points change in response to specific metal ions). These reports provide valuable information for designing and applying crown ether-based ion-responsive materials to various applications. For example, a selective and efficient methodology is required for removing metal ions from aqueous environments. To our knowledge, there has been no report of PNIPAM modified with the hydrophobic dibenzo-24-crown-8 (DB24C8) monomer. DB24C8 can recognize metal ions, including cesium, and thus the incorporation of DB24C8 into PNIPAM may provide a copolymer that is responsive to $\mathrm{Cs}^{+}$. In this paper we describe the synthesis of a new class of copolymers consisting of PNIPAM and DB24C8 using radical copolymerization with a DB24C8-carrying monomer. The properties of the resulting copolymers were investigated in the presence of various metal ions, including $\mathrm{Cs}^{+}$.

\section{Materials and Methods}

\subsection{Materials}

N-Isopropylacrylamide (NIPAM) was purchased from Wako Pure Chemical Industries (Osaka, Japan) and used after recrystallization from $n$-hexane. Acrylamide (AAM) and 2,2'-azobis(isobutyronitrile) (AIBN) were purchased from Nacalai Tesque Inc. (Kyoto, Japan). 2-Carboxydibenzo-24-crown-8 (1) was synthesized according to the reported procedure [27-29]. All other reagents were commercially available and used without further purification.

\subsection{Measurements}

${ }^{1} \mathrm{H}$ NMR spectra were recorded on a Bruker AVANCE $300 \mathrm{MHz}$ or AVANCE II $600 \mathrm{MHz}$ and the spectra were recorded at $300 \mathrm{~K}$. Mass spectra were taken on a Bruker microTOF or amazon SL mass spectrometer. IR spectra were recorded on a JASCO FT/IR-4600 spectrometer. Gel permeation chromatography (GPC) measurements were conducted using a system consisting of a JASCO PU-2089 pump, a CO-2065 column oven, an RI-2031 refractive index detector, and a Shodex KD-804 $(8.0 \mathrm{~mm} \times 300 \mathrm{~mm})$ column. DMF containing $10 \mathrm{mM} \mathrm{LiBr}$ was used as the eluent at a flow rate of $0.5 \mathrm{~mL} \mathrm{~min}^{-1}$ at $50^{\circ} \mathrm{C}$. Poly(methyl methacrylate) samples were used as standards. Transmittance was recorded using a JASCO V-550 UV-vis spectrometer. A $0.5 \mathrm{wt} \%$ polymer aqueous solution was filtered through a membrane filter $(0.45 \mu \mathrm{m})$, then the transmittance of the sample solution was measured in a quartz cell (cell length: $10 \mathrm{~mm}$ ) at $500 \mathrm{~nm}$ while heating at a rate of $0.5^{\circ} \mathrm{C} \mathrm{min}-1$.

\subsection{Synthesis of DB24C8 Monomer}

\section{$N$-(2-Carboxydibenzo-24-crown-8)-succinimide (2) [28,29]}

To a stirred solution of 2-carboxydibenzo-24-crown-8 (1) (478 mg, $0.970 \mathrm{mmol}$ ) and $\mathrm{N}$-hydroxysuccinimide $(113 \mathrm{mg}, 0.980 \mathrm{mmol})$ in DMF $(20 \mathrm{~mL})$ was added dicyclohexylcarbodiimide ( $263 \mathrm{mg}, 1.27 \mathrm{mmol})$. After addition, the reaction mixture was stirred at room temperature for $48 \mathrm{~h}$. The solution was filtered by suction filtration to filter off white precipitate and the filtrate was evaporated in vacuo. The crude product was purified by silica gel column chromatography (MeOH: $\mathrm{CH}_{2} \mathrm{Cl}_{2}=1: 19$ ) and recrystallized with isopropanol to afford compound 2 as a white solid (443.6 mg, yield 82\%). $R_{\mathrm{f}} 0.2\left(\mathrm{MeOH}: \mathrm{CH}_{2} \mathrm{Cl}_{2}=1: 19\right) ;{ }^{1} \mathrm{H} \mathrm{NMR}\left(300 \mathrm{MHz}, \mathrm{CDCl}_{3}\right) \delta 7.78(\mathrm{dd}, J=8.5$, $1.9 \mathrm{~Hz}, 1 \mathrm{H}), 7.55(\mathrm{~d}, J=1.9 \mathrm{~Hz}, 1 \mathrm{H}), 6.91-6.85(\mathrm{~m}, 5 \mathrm{H}), 4.23-4.14(\mathrm{~m}, 8 \mathrm{H}), 3.97-3.83(\mathrm{~m}, 16 \mathrm{H}), 2.90(\mathrm{~s}$, $4 \mathrm{H}) ;{ }^{13} \mathrm{C}$ NMR $\left(75 \mathrm{MHz}, \mathrm{CDCl}_{3}\right) \delta 169.4,161.5,154.6,148.9,148.6,125.6,121.44,121.39,117.2,114.7$, 114.0, 112.0, 71.6, 71.4, 71.3, 70.0, 69.6, 69.5, 69.4, 69.3, (some carbons are hidden into these peaks) 25.7; ESI-MS: $m / z 612.30(\mathrm{M}+\mathrm{Na})^{+}$, calcd. for $\mathrm{C}_{29} \mathrm{H}_{35} \mathrm{NO}_{12} \mathrm{Na}$ : 612.21 .

2-[(2-Aminoethyl) carbamoyl]dibenzo-24-crown-8 (3)

$\mathrm{N}$-(2-Carboxydibenzo-24-crown-8) succinimide ( $586 \mathrm{mg}, 0.990 \mathrm{mmol})$ in $\mathrm{CH}_{3} \mathrm{CN}(12 \mathrm{~mL})$ was added to ethylene diamine $(1.20 \mathrm{~g}, 20.0 \mathrm{mmol})$ in $\mathrm{CH}_{3} \mathrm{CN}(8 \mathrm{~mL})$ solution. After addition, the mixture 
was stirred at room temperature for $2 \mathrm{~h}$. Then the solution was filtered to remove precipitate and washed with $\mathrm{CH}_{3} \mathrm{CN}$. The filtrate was evaporated in vacuo to afford crude compound $\mathbf{3}$ as a pale yellow solid without further purification.

\section{2-(1,6-Dioxo-2,5-diaza-7-oxamyl)dibenzo-24-crown-8 (4)}

Acryloyl chloride $(0.15 \mathrm{~mL}, 1.84 \mathrm{mmol})$ was added to a mixture of crude compound 3 and triethylamine $(0.27 \mathrm{~mL}, 1.94 \mathrm{mmol})$ in $\mathrm{CH}_{2} \mathrm{Cl}_{2}(6 \mathrm{~mL})$ solution at $0{ }^{\circ} \mathrm{C}$. After addition, the resulting mixture was stirred at $0{ }^{\circ} \mathrm{C}$ for $1 \mathrm{~h}$, and then stirred at room temperature for $19 \mathrm{~h}$. The reaction was quenched by saturated sodium bicarbonate solution $(6 \mathrm{~mL})$ and diluted with $\mathrm{CH}_{2} \mathrm{Cl}_{2}$. After extraction, the water layer was re-extracted with $\mathrm{CH}_{2} \mathrm{Cl}_{2}$. The combined organic layer was washed with saturated $\mathrm{NaCl}$ aqueous solution, dried over $\mathrm{MgSO}_{4}$, filtered, and evaporated in vacuo. The crude product was purified by silica gel column chromatography (MeOH:CH $\left.\mathrm{Cl}_{2}=1: 19\right)$ to afford compound 4 as a white solid (396.7 mg, two steps yield 68\%). $R_{\mathrm{f}} 0.15$ (MeOH: $\mathrm{CH}_{2} \mathrm{Cl}_{2}=1: 9$ ); IR (KBr) 3294, 3082, 2931, 2873, 1658, 1629, 1602, 1594, 1582, 1543, $1507 \mathrm{~cm}^{-1} ;{ }^{1} \mathrm{H}$ NMR $\left(600 \mathrm{MHz}, \mathrm{CDCl}_{3}\right) \delta 7.42(\mathrm{~s}, 1 \mathrm{H}), 7.39$ $(\mathrm{d}, J=1.8 \mathrm{~Hz}, 1 \mathrm{H}), 7.35(\mathrm{dd}, J=8.3,1.8 \mathrm{~Hz}, 1 \mathrm{H}), 6.93(\mathrm{~s}, 1 \mathrm{H}), 6.89-6.85(\mathrm{~m}, 4 \mathrm{H}), 6.82(\mathrm{~d}, J=8.3 \mathrm{~Hz}, 1 \mathrm{H})$, $6.26(\mathrm{dd}, J=17.0,1.0 \mathrm{~Hz}, 1 \mathrm{H}), 6.14(\mathrm{dd}, J=17.0,10.3 \mathrm{~Hz}, 1 \mathrm{H}), 5.62(\mathrm{dd}, J=10.3,1.0 \mathrm{~Hz}, 1 \mathrm{H}), 4.19-4.13(\mathrm{~m}$, 8H), 3.92-3.90 (m, 8H), 3.83-3.82 (m, 8H), $3.54(\mathrm{~s}, 4 \mathrm{H})$ (Figure S1 (Supplementary Materials)); ${ }^{13} \mathrm{C}$ NMR $\left(150 \mathrm{MHz}, \mathrm{CDCl}_{3}\right) \delta 168.0,167.1,151.7,148.9,148.5,130.7,126.8,126.6,121.5,120.4,114.2,112.7,112.6$, 71.3, 71.24, 71.21, 71.20, 69.9, 69.8, 69.7, 69.41, 69.38, 69.34, 69.31, 41.1, 40.0 (Figure S2 (Supplementary Materials)); ESI-MS: $m / z$ 611.212 (M+ Na) ${ }^{+}$, calcd. for $\mathrm{C}_{30} \mathrm{H}_{40} \mathrm{~N}_{2} \mathrm{O}_{10} \mathrm{Na}$ : 611.258.

\subsection{Synthesis of DB24C8-Bearing Copolymers}

All copolymers were synthesized by free-radical copolymerization using AIBN as an initiator in dimethyl sulfoxide (DMSO) as a solvent. Total monomer concentration was $1.0 \mathrm{M}$ and the molar ratio of AIBN in the total monomer was $1 \mathrm{~mol} \%$. NIPAM, DB24C8 monomer (4), and AAM were dissolved in $1.5 \mathrm{~mL}$ DMSO in a glass tube. The resulting solution was degassed by at least three freeze-thaw cycles, then the glass tube was filled with nitrogen and heated at $70{ }^{\circ} \mathrm{C}$ for $24 \mathrm{~h}$. The products were purified by dialysis (Spectra/Por 7 MWCO 1000, Spectrum Laboratories, Inc., Rancho Dominguez, California, CA, USA) against deionized water and freeze-dried to give copolymers. ${ }^{1} \mathrm{H}$ NMR spectra are shown in Figures S3-S11 (Supplementary Materials).

\subsection{Binding Test of Copolymers with Metal Ions by ${ }^{1} H$ NMR}

A DMSO- $d_{6}$ solution $(750 \mu \mathrm{L})$ containing $\mathbf{P 7}$ or $\mathbf{P 9}(7.5 \mathrm{mg})$ and a $\mathrm{D}_{2} \mathrm{O}$ solution $(100 \mu \mathrm{L})$ containing alkali metal chloride $(0.0143 \mathrm{mmol}$ of $\mathrm{LiCl}, \mathrm{CsCl}$ for $\mathrm{P7}, 0.0243 \mathrm{mmol}$ of $\mathrm{LiCl}, \mathrm{NaCl}, \mathrm{KCl}, \mathrm{RbCl}, \mathrm{CsCl}$ for P9) were mixed to form copolymer-metal ion solution in DMSO- $d_{6}: \mathrm{D}_{2} \mathrm{O}=7.5: 1 v / v$ and recorded. For the competition test, a DMSO- $d_{6}$ solution $(450 \mu \mathrm{L})$ containing P9 $(4.5 \mathrm{mg})$ and a $\mathrm{D}_{2} \mathrm{O}$ solution $(60 \mu \mathrm{L})$ containing cesium chloride $(0.0146 \mathrm{mmol}, 2.5 \mathrm{mg})$ and other alkali metal chlorides $(\mathrm{NaCl}$ or $\mathrm{KCl}$ ) were mixed and recorded on a Bruker AVANCE II $600 \mathrm{MHz}$.

\section{Results and Discussion}

\subsection{Synthesis of DB24C8-Bearing Copolymers}

The DB24C8-carrying AAM derivative was synthesized as outlined in Scheme 1. First, the succinimide ester derivative of DB24C8 (2) was obtained from the carboxylic acid-functionalized DB24C8 (1) using a literature procedure [29,30]. Next, the activated ester of DB24C8 (2) was reacted with excess ethylenediamine to obtain compound 3, followed by reaction with acryloyl chloride to yield 2-(1,6-dioxo-2,5-diaza-7-oxamyl)dibenzo-24-crown-8 (4) as a monomer used for synthesizing the DB24C8-bearing copolymers. A radical copolymerization reaction was carried out using 4, NIPAM, and AAM as monomers, and AIBN as an initiator (Scheme 2). The series of 
DB24C8-bearing copolymers obtained using various well-controlled feed ratios is summarized in Table 1.<smiles>O=C(O)c1ccc(OCCOCCOCCOc2ccccc2OCCOCCOCCO)c(OCCO)c1</smiles>

1 (a)<smiles>O=C(ON1C(=O)CCC1=O)c1ccc(OCCOCCOCCOc2ccccc2OCCOCCOCCO)c(OCCO)c1</smiles>

(b)<smiles>NCCNC(=O)c1ccc(OCCOCCOCCOc2ccccc2OCCOCCOCCO)c(OCCO)c1</smiles>

2

(c)<smiles>C=CC(=O)NCCNC(=O)c1ccc(OCCOCCOCCOc2ccccc2OCCOCCOCCO)c(OCCOC)c1</smiles>

4

Scheme 1. Synthesis of dibenzo-24-crown-8 (DB24C8) monomer. (a): N-Hydroxysuccinimide, dicyclohexylcarbodiimide, $\mathrm{DMF}$, r.t., 48 h, $82 \%$; (b): Ethylenediamine, $\mathrm{CH}_{3} \mathrm{CN}$, r.t., 2 h; (c): Acryloyl chloride, triethylamine, $\mathrm{CH}_{2} \mathrm{Cl}_{2}, 0{ }^{\circ} \mathrm{C}-$ r.t., $20 \mathrm{~h}, 68 \%$ (two steps $(\mathrm{b}, \mathrm{c})$ ).

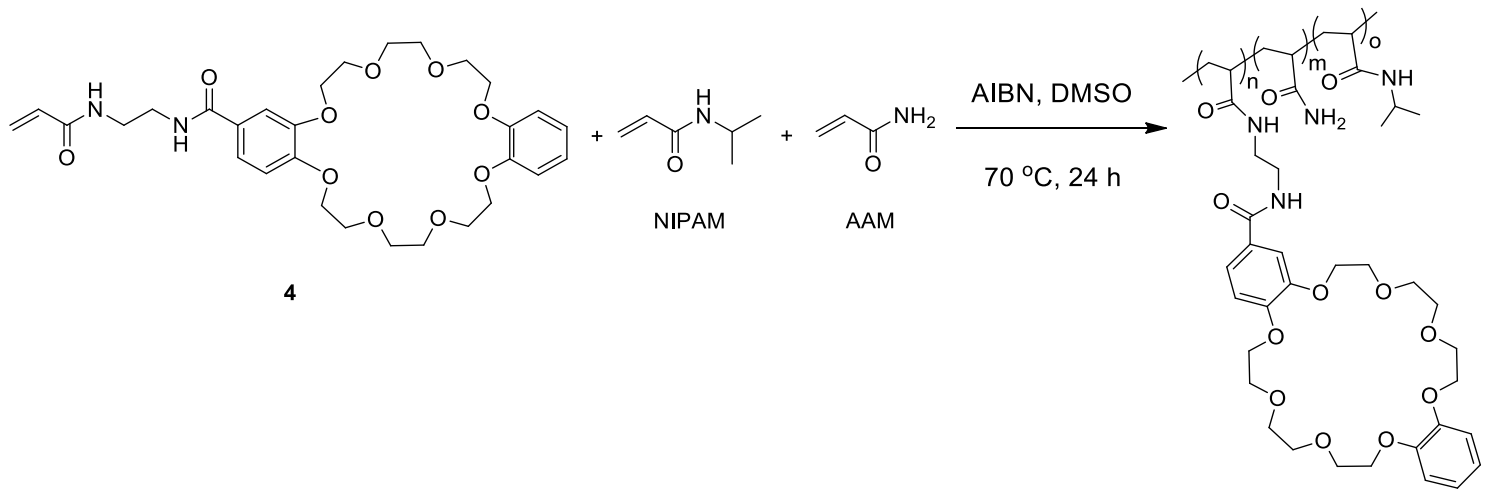

Scheme 2. Synthesis of copolymer bearing DB24C8. NIPAM: N-isopropylacrylamide; AAM: acrylamide; AIBN: 2,2'-azobis(isobutyronitrile); DMSO: dimethyl sulfoxide.

Table 1. Synthesis of copolymers bearing DB24C8.

\begin{tabular}{|c|c|c|c|c|c|c|}
\hline Polymer & $\begin{array}{l}\text { Feed Molar Ratio of } \\
\text { NIPAM/4/AAM }\end{array}$ & $\operatorname{Conv}(\%)^{a}$ & Yield (\%) & $\begin{array}{c}M_{\mathrm{w}}{ }^{\mathrm{c}} \\
\left(\times 10^{-3}\right)\end{array}$ & $M_{\mathrm{w}} / M_{\mathrm{n}}{ }^{\mathrm{c}}$ & $\begin{array}{c}\text { Molar Ratio of } \\
\text { NIPAM/4/AAM } \\
\text { in Polymer }^{\text {a }}\end{array}$ \\
\hline P2 & $97.0 / 3.0 / 0$ & 92 & 95 & 248 & 1.62 & $97.1 / 2.9 / 0$ \\
\hline P3 & $95.0 / 5.0 / 0$ & 82 & 63 & 158 & 2.43 & $95.8 / 4.2 / 0$ \\
\hline $\mathbf{P 4}$ & $93.5 / 6.5 / 0$ & 95 & 76 & 210 & 2.02 & $93.7 / 6.3 / 0$ \\
\hline P6 & $82.0 / 3.0 / 15$ & 98 & 80 & 244 & 1.54 & $85.7 / 2.4 / 11.9$ \\
\hline P7 & $80.0 / 5.0 / 15$ & 87 & 94 & 197 & 2.00 & $85.6 / 5.0 / 9.4$ \\
\hline P8 & $77.5 / 7.5 / 15$ & 98 & 84 & 176 & 2.95 & $81.7 / 7.6 / 10.7$ \\
\hline P9 & $75.0 / 10 / 15$ & 85 & 93 & 127 & 2.47 & $82.6 / 10.5 / 6.9$ \\
\hline
\end{tabular}

${ }^{\mathrm{a}}$ Determined by ${ }^{1} \mathrm{H}$ NMR; ${ }^{\mathrm{b}}$ Isolated yield; ${ }^{\mathrm{c}}$ Determined by GPC. 


\subsection{Cloud Points Analysis of DB24C8-Bearing Copolymers}

The cloud points of copolymers in water were determined by turbidity experiments conducted at various temperatures. Figure 1 shows the change in transmittance of the synthesized copolymer solutions with temperature. The cloud point of each copolymer changed sharply following the incorporation of a small amount of DB24C8 monomer. For example, the introduction of $2.9 \%$ and $4.2 \%$ DB24C8 monomer, generating $\mathbf{P 2}$ and $\mathbf{P} 3$, resulted in the cloud point decreasing from $31.1{ }^{\circ} \mathrm{C}(\mathbf{P} 1$ : PNIPAM) to $23.0^{\circ} \mathrm{C}(\mathbf{P 2})$ and $16.5^{\circ} \mathrm{C}(\mathbf{P} 3)$, respectively (Figure 1a). The introduction of $15 \%$ AAM as a hydrophilic co-monomer resulted in an increase in the cloud point compared with in the absence of AAM. An increase in DB24C8 monomer to $2.4 \%$ and $5.0 \%$ resulted in the cloud points of the $\mathbf{P 6}$ and P7 copolymers containing AAM decreasing from $42.4{ }^{\circ} \mathrm{C}$ (P5: without DB24C8) to $28.9^{\circ} \mathrm{C}$ (P6) and $16.2^{\circ} \mathrm{C}(\mathbf{P 7})$, respectively (Figure $\left.1 \mathrm{~b}\right)$. The cloud point of P8, containing $7.6 \%$ DB24C8 monomer, was estimated to decrease to approximately $4-5^{\circ} \mathrm{C}$, as the sample did not solidify even upon refrigeration. The cloud point of $\mathbf{P 9}$, containing $10.5 \%$ DB24C8 monomer, is likely lower than that of $\mathbf{P 8}$, and could be around $0{ }^{\circ} \mathrm{C}$ as estimated by the observation of copolymer solution in an ice bath.

(a)

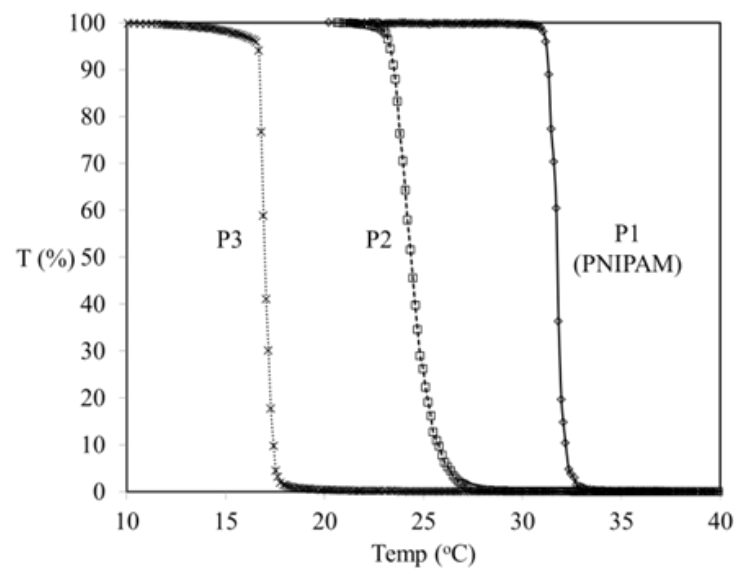

(b)

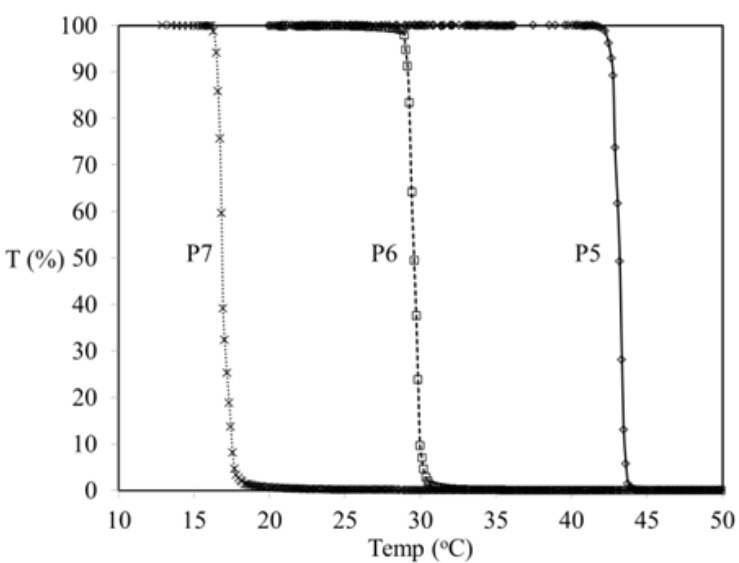

Figure 1. Transmittance of copolymers $(0.5 \mathrm{wt} \%)$ in water.

\subsection{Cesium Ion Binding to the DB24C8-Bearing Copolymers}

We investigated the cloud points of $\mathbf{P 7}$ and $\mathbf{P 8}$ in aqueous solution with/without $\mathrm{Cs}^{+}$, and the results are shown in Table 2 and Figure 2. The cloud point of P7 (DB24C $8=5.0 \%$ ) increased slightly $\left(0.7^{\circ} \mathrm{C} ; 16.2 \rightarrow 16.9^{\circ} \mathrm{C}\right)$ in the presence of $\mathrm{Cs}^{+}$, whereas a larger cloud point shift (approximately $4-5^{\circ} \mathrm{C}$ ) was observed for $\mathrm{P8}$ (DB24C8 $=7.6 \%$ ). The increase in cloud point in the presence of $\mathrm{Cs}^{+}$may be due to repulsion between charged DB24C8-Cs ${ }^{+}$complexes and an increase in hydrophilicity, as observed with PNIPAM bearing 18-crown-6 ether binding specific metal ions such as $\mathrm{Pb}^{2+}$ and $\mathrm{Ba}^{2+}$ [25]. An increase in DB24C8 monomer resulted in an increased cloud point shift, suggesting that the cloud point shift with P9, which contains a higher percentage of DB24C8 (10.5\%), would be larger than that of P7 in the presence of $\mathrm{Cs}^{+}$.

Table 2. Cloud point values of P7, P8, and P9 with/without Cs+ in water.

\begin{tabular}{ccc}
\hline Polymer & Without $\mathrm{Cs}^{+}\left({ }^{\circ} \mathrm{C}\right)$ & With $\mathrm{Cs}^{+}\left({ }^{\circ} \mathrm{C}\right)$ \\
\hline P7 & 16.2 & 16.9 \\
P8 & $4-5^{\mathrm{a}}$ & 9.2 \\
P9 & $-3-0^{\mathrm{b}}$ & $0-1^{\mathrm{b}}$
\end{tabular}

a Estimated by the observation of copolymer solution in a refrigerator (approximately $4{ }^{\circ} \mathrm{C}$ ); ${ }^{\mathrm{b}}$ Estimated by the observation of copolymer solution in an ice bath. 


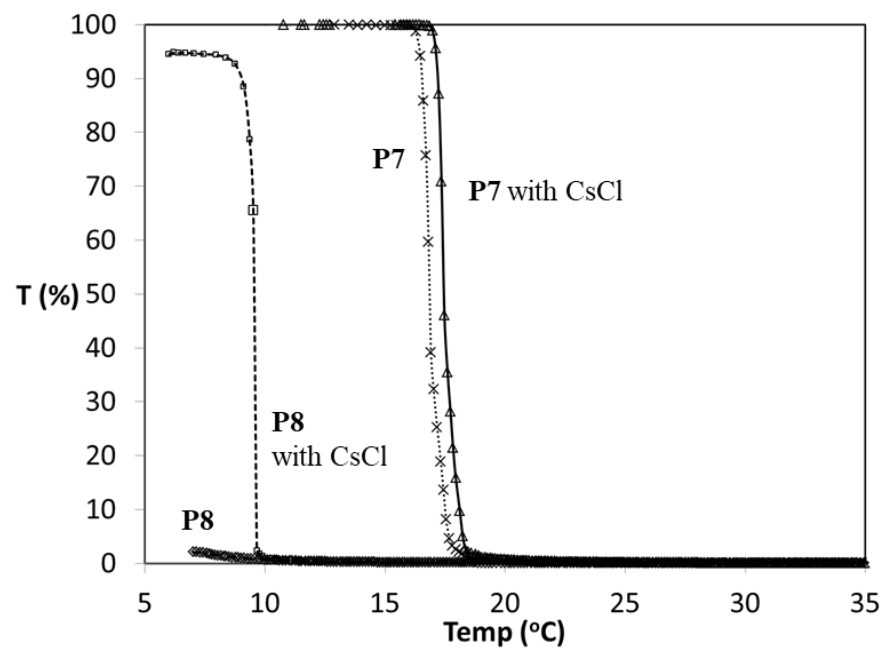

Figure 2. Transmittance of copolymers $(0.5 \mathrm{wt} \%)$ in water in the absence/presence of $\mathrm{CsCl}$.

Next, we investigated the binding properties of copolymers bearing DB24C8 with various alkali metal ions using ${ }^{1} \mathrm{H}$ NMR. The addition of $\mathrm{Cs}^{+}$to copolymer solution resulted in a clear shift in the aromatic and methylene proton signals at 6.9 and $4.0 \mathrm{ppm}$, respectively, attributed to DB24C8 (Figures $3 \mathrm{c}$ and $4 \mathrm{f}$ ), compared to in the absence of alkali metal (Figures $3 \mathrm{a}$ and $4 \mathrm{a}$ ). No signal shift was observed following the addition of $\mathrm{Li}^{+}$(Figures $3 \mathrm{~b}$ and $4 \mathrm{~b}$ ). The addition of the alkali metal ions $\mathrm{K}^{+}, \mathrm{Rb}^{+}$, and $\mathrm{Cs}^{+}$resulted in gradual signal shifts of DB24C8, which increased with increasing ion size (Figure $4 \mathrm{~d}-\mathrm{f}$; chemical shift changes $(\Delta \delta)$ are summarized in Table 3 and Table S1 (Supplementary Materials), suggesting that the binding affinity of copolymer bearing DB24C8 for alkali metal ion increases as the size of the ion increases. These trends of chemical shift change were similar to the results in the literature [7]. The $\Delta \delta$ of $\mathbf{P 9}(\Delta \delta=0.037)$ was larger than that of $\mathbf{P 7}(\Delta \delta=0.028)$ in the presence of $\mathrm{Cs}^{+}$, suggesting that the binding affinity for $\mathrm{Cs}^{+}$of the higher DB24C8-content copolymer P9 (DB24C8 $=10.5 \%)$ was higher than that of the lower DB24C8-content copolymer P7 (DB24C8 $=5.0 \%$ ). Copolymer bearing DB24C8 P9 exhibited the strongest binding for the large alkali metal ion $\mathrm{Cs}^{+}$in the series of alkali metal ions tested in this study. The cavity diameter of DB24C8 is estimated to be about 4.5-5.0 $\AA$ [31,32], and is thus suitable for recognizing $\mathrm{Cs}^{+}$(which has a diameter of $3.34 \AA$ ) [33]. Theoretically, P9 can absorb $87 \mathrm{mg}$-Cs /g-copolymer if a crown ether molecule fully forms 1:1 binding with cesium ion.

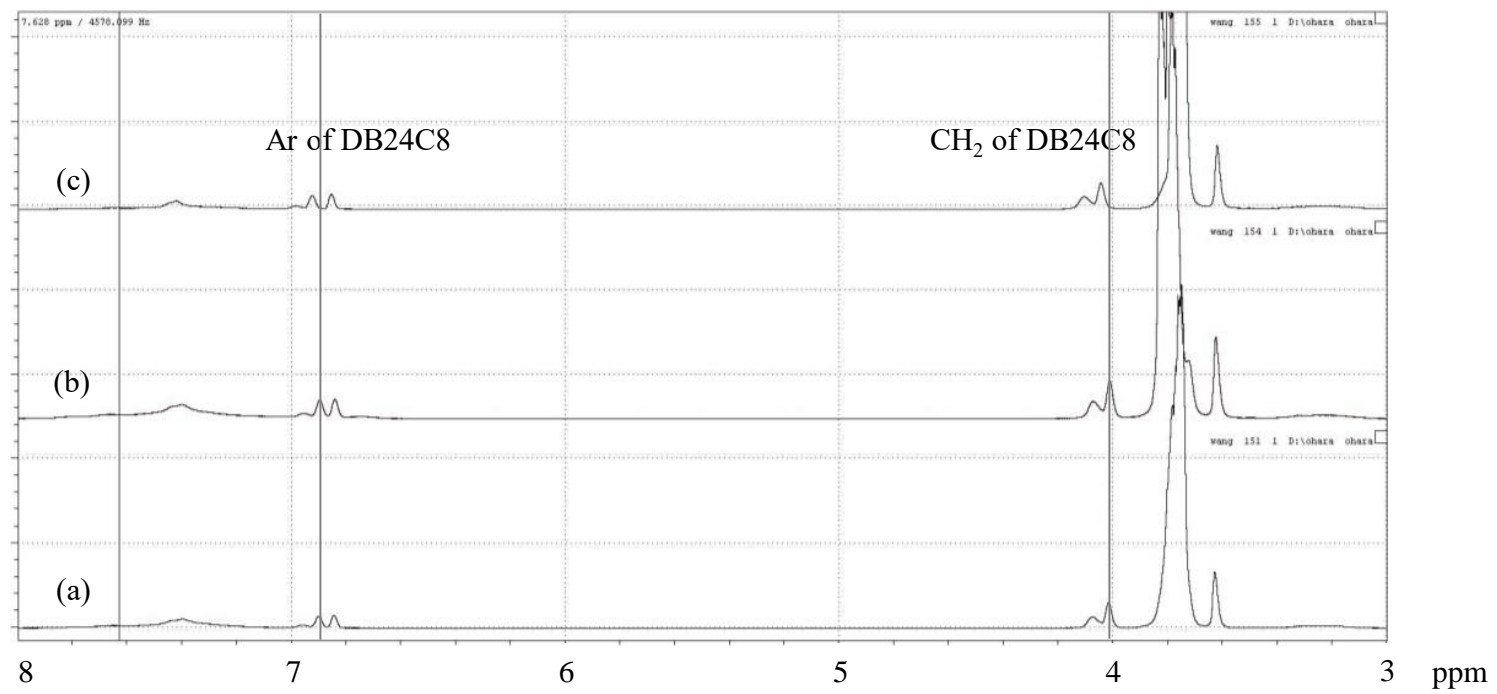

Figure 3. ${ }^{1} \mathrm{H}$ NMR spectra of $\mathbf{P 7}$ in the presence of alkali metal salt: (a) None; (b) $\mathrm{LiCl}$; (c) $\mathrm{CsCl}$. 


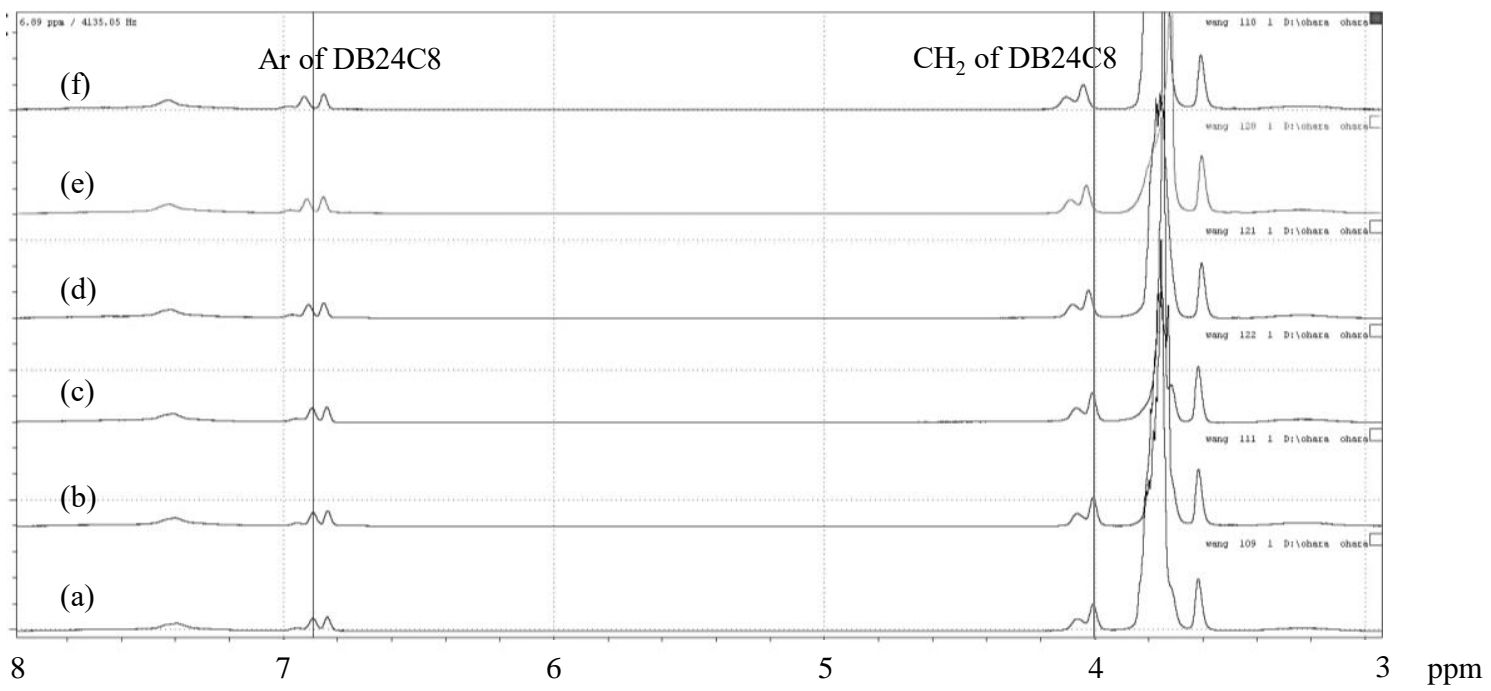

Figure 4. ${ }^{1} \mathrm{H}$ NMR spectra of $\mathbf{P 9}$ in the presence of alkali metal salt: (a) None; (b) $\mathrm{LiCl}$; (c) $\mathrm{NaCl}$; (d) $\mathrm{KCl}$; (e) $\mathrm{RbCl}$; (f) $\mathrm{CsCl}$.

Table 3. Chemical shifts $(\delta)$ and their changes $(\Delta \delta)$ of methylene protons of DB24C8 in P9 in the presence of alkali metal salt.

\begin{tabular}{ccccccc}
\hline & None & $\mathbf{L i}^{+}$ & $\mathbf{N a}^{+}$ & $\mathbf{K}^{+}$ & $\mathbf{R b}^{+}$ & $\mathbf{C s}^{+}$ \\
\hline Cation diameter $(\AA)[33]$ & - & 1.20 & 1.90 & 2.66 & 2.96 & 3.34 \\
$\delta(\mathrm{ppm})$ & 4.005 & 4.006 & 4.008 & 4.022 & 4.030 & 4.042 \\
$\Delta \delta(\mathrm{ppm})$ & - & 0.001 & 0.003 & 0.017 & 0.025 & 0.037 \\
\hline
\end{tabular}

Competition tests of $\mathrm{Cs}^{+}$with other alkali metal ions were performed to investigate the binding selectivity of DB24C8 in the copolymer (Figures S12 and S13 (Supplementary Materials)). Table 4 shows the $\Delta \delta$ of methylene protons of DB24C8 in the copolymer P9. The addition of $\mathrm{Cs}^{+}$to the copolymer solution in the presence of other $\mathrm{Na}^{+}$and $\mathrm{K}^{+}$ions resulted in clear shifts in the methylene proton signal at $4.0 \mathrm{ppm}$. Clear signal shifts were observed with high $\mathrm{Na}^{+}$or $\mathrm{K}^{+}(\mathrm{CsCl}: \mathrm{NaCl}$ or $\mathrm{KCl}=1: 5)$. These results indicate that the binding affinity of DB24C8 in the copolymer is higher for $\mathrm{Cs}^{+}$than that of $\mathrm{Na}^{+}$and $\mathrm{K}^{+}$, suggesting that this adsorption system can remove $\mathrm{Cs}^{+}$from an environment also including $\mathrm{Na}^{+}$and $\mathrm{K}^{+}$.

Table 4. Chemical shifts $(\delta)$ and their changes $(\Delta \delta)$ of methylene protons of DB24C8 in P9 in the competition test.

\begin{tabular}{ccccccccc}
\hline & None & $\mathrm{NaCl}$ & $\mathrm{KCl}$ & $\mathrm{CsCl}$ & $\begin{array}{c}\mathrm{CsCl}+\mathrm{NaCl} \\
(\mathrm{CsCl}: \mathrm{NaCl}=1: 1)\end{array}$ & $\begin{array}{c}\mathrm{CsCl}+\mathrm{NaCl} \\
(\mathrm{CsCl}: \mathrm{NaCl}=1: 5)\end{array}$ & $\begin{array}{c}\mathrm{CsCl}+\mathrm{KCl} \\
(\mathrm{CsCl}: \mathrm{KCl}=1: 1)\end{array}$ & $\begin{array}{c}\mathrm{CsCl}+\mathrm{KCl} \\
(\mathrm{CsCl}: \mathrm{KCl}=1: 5)\end{array}$ \\
\hline$\delta(\mathrm{ppm})$ & 4.005 & 4.008 & 4.022 & 4.042 & 4.043 & 4.040 & 4.047 & 4.054 \\
$\Delta \delta(\mathrm{ppm})$ & - & 0.003 & 0.017 & 0.037 & 0.038 & 0.035 & 0.042 & 0.049 \\
\hline
\end{tabular}

\section{Conclusions}

Copolymers bearing DB24C8 were synthesized by radical copolymerization using a DB24C8-carrying AAM derivative and NIPAM as a monomer substrate. The cloud points of the copolymers decreased following the incorporation of a low content of hydrophobic DB24C8. The use of $15 \%$ hydrophilic AAM increased the cloud points of the DB24C 8 copolymers. These copolymers bound alkali metal ions in aqueous solution, and the binding affinity was dependent on the size of the alkali metal ion. Our findings suggest that DB24C8-bearing polymers hold promise for adsorbing and removing cesium from the environment when used in conjunction with membrane separation including ultrafiltration, or with precipitation by centrifugation above the cloud point in which condition the NIPAM-based copolymers aggregate. 
Supplementary Materials: The following are available online at http:/ / www.mdpi.com/2073-4360/10/10/1095/ s1, Figures S1-S11: NMR spectra of 4 and P1-P9, Figures S12 and 13: competition tests using P9 by ${ }^{1} \mathrm{H}$ NMR analysis, Table S1: Chemical shifts $(\delta)$ and their changes $(\Delta \delta)$ of methylene protons of DB24C8 in P7 in the presence of alkali metal salt.

Author Contributions: T.T. conceived the project, designed the experiments, directed the research; D.M.W. performed the experiment; D.M.W. and T.T. wrote the paper; Y.A. and H.O. contributed to interpretation of data and reviewed the manuscript. All authors discussed the results and edited the manuscript.

Acknowledgments: We would like to thank David Nielsen (Arizona State University, USA) for helpful discussions.

Conflicts of Interest: The authors declare no conflict of interest.

\section{References}

1. Yin, J.; Hu, Y.; Yoon, J. Fluorescent probes and bioimaging: Alkali metals, alkaline earth metals and $\mathrm{pH}$. Chem. Soc. Rev. 2015, 44, 4619-4644. [CrossRef] [PubMed]

2. Shamsipur, M.; Rajabi, H.R. Flame photometric determination of cesium ion after its preconcentration with nanoparticles imprinted with the cesium-dibenzo-24-crown-8 complex. Microchim. Acta 2013, 180, $243-252$. [CrossRef]

3. Choi, T.A.; Costes, S.V.; Abergel, R.J. Understanding the health impacts and risks of exposure to radiation. In Reflections on the Fukushima Daiichi Nuclear Accident: Toward Social-Scientific Literacy and Engineering Resilience; Ahn, J., Carson, C., Jensen, M., Juraku, K., Nagasaki, S., Tanaka, S., Eds.; Springer: London, UK, 2015; pp. 259-281. ISBN 978-3-319-12089-8.

4. Yu, H.-R.; Hu, J.-Q.; Liu, Z.; Ju, X.-J.; Xie, R.; Wang, W.; Chu, L.-Y. Ion-recognizable hydrogels for efficient removal of cesium ions from aqueous environment. J. Hazard. Mater. 2017, 323, 632-640. [CrossRef] [PubMed]

5. Pedersen, C.J. The Discovery of Crown Ethers (Noble Lecture). Angew. Chem. Int. Ed. 1988, 27, 1021-1027. [CrossRef]

6. Gokel, G.W.; Leevy, W.M.; Weber, M.E. Crown ethers: Sensors for ions and molecular scaffolds for materials and biological models. Chem. Rev. 2004, 104, 2723-2750. [CrossRef] [PubMed]

7. Sakata, Y.; Kobayashi, S.; Akine, S. Two-step modulation of ion recognition using a bis(saloph)-macrocyclic host having a 24-crown-8-like cavity. Chem. Commun. 2017, 53, 6363-6366. [CrossRef] [PubMed]

8. Takeda, Y. The solvent extraction of uni- and bivalent metal picrates by dibenzo-24-crown-8. Bull. Chem. Soc. Jpn. 1979, 52, 2501-2504. [CrossRef]

9. Shamsipur, M.; Rounaghi, G.; Popov, A.I. Sodium-23, cesium-133 and thallium-205 NMR study of sodium, cesium and thallium complexes with large crown ethers in nonaqueous solutions. J. Solut. Chem. 1980, 9, 701-714. [CrossRef]

10. Shinkai, S.; Kinda, H.; Manabe, O. Photoresponsive complexation of metal cations with an azobenzene-crown-azobenzene bridge immobilized in polymer supports. J. Am. Chem. Soc. 1982, 104, 2933-2934. [CrossRef]

11. Tawarah, K.M.; Mizyed, S.A. A conductance study of the association of alkali cations with 1,13-dibenzo-24-crown-8 in acetonitrile. J. Solut. Chem. 1989, 18, 387-401. [CrossRef]

12. Srivastava, S.K.; Gupta, V.K.; Dwivedi, M.K.; Jain, S. Caesium PVC-crown (dibenzo-24-crown-8) based membrane sensor. Anal. Proc. Incl. Anal. Commun. 1995, 32, 21-23. [CrossRef]

13. Rofouei, M.K.; Taghdiri, M.; Shamsipur, M.; Alizadeh, K. ${ }^{133}$ Cs NMR study of $\mathrm{Cs}^{+}$ion complexes with dibenzo-24-crown-8, dicyclohexano-24-crown-8 and dibenzo-30-crown-10 in binary acetonitrile-nitromethane mixtures. J. Solut. Chem. 2010, 39, 1350-1359. [CrossRef]

14. Vibhute, R.G.; Khopkar, S.M. Solvent extraction separation of cesium with dibenzo-24-crown-8 from picrate solution. J. Radioanal. Nucl. Chem. 1991, 152, 487-496. [CrossRef]

15. Awual, M.R.; Yaita, T.; Taguchi, T.; Shiwaku, H.; Suzuki, S.; Okamoto, Y. Selective cesium removal from radioactive liquid waste by crownether immobilized new class conjugate adsorbent. J. Hazard. Mater. 2014, 278, 227-235. [CrossRef] [PubMed]

16. Nakayama, M.; Okano, T.; Winnik, F.M. Poly( $N$-isopropylacrylamide)-based smart surfaces for cell sheet tissue engineering. Mater. Matters 2010, 5, 56. 
17. Irie, M.; Misumi, Y.; Tanaka, T. Stimuli-responsive polymers: Chemical induced reversible phase separation of an aqueous solution of poly( $N$-isopropylacrylamide) with pendent crown ether groups. Polymer 1993, 34, 4531-4535. [CrossRef]

18. Qiu, Y.; Park, K. Environment-sensitive hydrogels for drug delivery. Adv. Drug Deliv. Rev. 2001, 53, 321-339. [CrossRef]

19. Yi, R.; Ye, G.; Lv, D.; Chen, J. Novel thermo-responsive hydrogel microspheres with calixcrown host molecules as cross-links for highly specific binding and controllable release of cesium. RSC Adv. 2015, 5, 55277-55284. [CrossRef]

20. Cheng, J.; Shan, G.; Pan, P. Temperature and pH-dependent swelling and copper(II) adsorption of poly(Nisopropylacrylamide) copolymer hydrogel. RSC Adv. 2015, 5, 62091-62100. [CrossRef]

21. Deng, M.; Wang, Y.; Men, G.; Shang, H.; Jiang, S. Reusable highly sensitive and selective fluorescent sensor for $\mathrm{Hg}^{2+}$ detection in water based on a thermoresponsive copolymer. Sens. Actuators B Chem. 2016, 234, 609-615. [CrossRef]

22. Tanaka, T.; Okamoto, M. Reversible Temperature-responsive and Lectin-recognizing Glycosylated Block Copolymers Synthesized by RAFT Polymerization. Polym. J. 2018, 50, 523-531. [CrossRef]

23. Tanaka, T.; Okamoto, M. Lectin and Temperature Dual-responsive Glycosylated Block Copolymers Synthesized by Consecutive RAFT Polymerization Reactions. Bull. Chem. Soc. Jpn. 2018, 91, 727-777. [CrossRef]

24. Zhang, B.; Ju, X.-J.; Xie, R.; Liu, Z.; Pi, S.-W.; Chu, L.-Y. Comprehensive effects of metal ions on responsive characteristics of P(NIPAM-co-B18C6Am). J. Phys. Chem. B 2012, 116, 5527-5536. [CrossRef] [PubMed]

25. Yu, H.-R.; Hu, J.-Q.; Lu, X.-H.; Ju, X.-J.; Liu, Z.; Xie, R.; Wang, W.; Chu, L.-Y. Insights into the effects of 2:1 "sandwich-type" crown-ether/metal-ion complexes in responsive host-guest systems. J. Phys. Chem. B 2015, 119, 1696-1705. [CrossRef] [PubMed]

26. Ju, X.-J.; Chu, L.-Y.; Mi, P.; Song, H.; Lee, Y.M. Synthesis and characterization of a novel thermo-sensitive copolymer of N-isopropylacrylamide and dibenzo-18-crown -6-diacrylamide. Macromol. Rapid Commun. 2006, 27, 2072-2077. [CrossRef]

27. Liu, D.; Wang, D.; Wang, M.; Zheng, Y.; Koynov, K.; Auernhammer, G.K.; Butt, H.-J.; Ikeda, T. Supramolecular organogel based on crown ether and secondary ammoniumion functionalized glycidyl triazole polymers. Macromolecules 2013, 46, 4617-4625. [CrossRef]

28. Iqbal, P.; Rawson, F.J.; Ho, W.K.-W.; Lee, S.-F.; Leung, K.C.-F.; Wang, X.; Beri, A.; Preece, J.A.; Ma, J.; Mendes, P.M. Surface molecular tailoring using $\mathrm{pH}$-switchable supramolecular dendron-ligand assemblies. ACS Appl. Mater. Interfaces 2014, 6, 6264-6274. [CrossRef] [PubMed]

29. Wang, D.-M.; Tanaka, T.; Aoki, T.; Aso, Y.; Minami, H.; Ohara, H. Synthesis of dibenzo-24-crown-8 conjugated chitosan with different amide bond coupling methods. Lett. Org. Chem. 2018, 15, 214-220. [CrossRef]

30. Jones, J.W.; Bryant, W.S.; Bosman, A.W.; Janssen, R.A.J.; Meijer, E.W.; Gibson, H.W. Crowned dendrimers: pH-responsive pseudorotaxane formation. J. Org. Chem. 2003, 68, 2385-2389. [CrossRef] [PubMed]

31. Alizadeh, N.; Roomiani, A. Kinetic study of charge transfer complexes of iodine with some crown ethers in nonaqueous solvents. J. Chil. Chem. Soc. 2012, 57, 1130-1133. [CrossRef]

32. Chamsaz, M.; Rounaghi, G.H.; Sovizi, M.R. Polarographic study of the interaction of $\mathrm{Tl}^{+}, \mathrm{Pb}^{2+}$ and $\mathrm{Cd}^{2+}$ cations with 18-crown-6 in binary non-aqueous solvents. Russ. J. Inorg. Chem. 2005, 50, 413-417.

33. Pedersen, C.J. Cyclic polyethers and their complexes with metal salts. J. Am. Chem. Soc. 1967, 89, 7017-7036. [CrossRef]

(C) 2018 by the authors. Licensee MDPI, Basel, Switzerland. This article is an open access article distributed under the terms and conditions of the Creative Commons Attribution (CC BY) license (http://creativecommons.org/licenses/by/4.0/). 